

All together now: a proposed children's study will look at how biology and the environment interact.

\section{Huge study of children aims to get the dirt on development}

\section{Erika Check, Washington}

The architects of a study that would follow 100,000 American children from conception to adulthood have unveiled their plans after four years of preparation.

The designers of the National Children's Study, which would cost $\$ 2.7$ billion to run, hope to collect a wealth of information. Sources will range from blood taken from mothers before pregnancy to samples of the dirt found in children's homes, schools and playgrounds. The studyblueprint, released on 16 November, also calls for information to be collected on the children's genes, chemicals in their bodies and the structure of their families.

The data will shed light on the broad issue of how biology and the environment interact to cause diseases and developmental disorders. But the study team, which is based at the National Institute of Child Health and Human Development in Rockville, Maryland, is particularly interested in areas such as obesity, mental disorders and issues involving pregnancy, including birth weight and birth defects.

"There's a lot of hope pinned on this," says study adviser Nancy Green, medical director of the March of Dimes in White Plains, New York, which lobbies on health issues in babies. Green says the study could be as crucial as the famous Framingham Heart Study, which has followed residents of a town in Massachusetts since 1948 and is credited with having revolutionized the treatment of cardiovascular disease.

The study could also get to the roots of rare disorders, such as types of childhood cancer, by sharing data with similar efforts in other countries. Investigators in Scandinavia, for example, this year began collecting biological samples and data on 200,000 Danish and Norwegian children, although they are not directly sampling the children's environment.

The child health institute, which was given $\$ 50$ million of government funding in 2000 to plan the study, now needs to persuade Congress to fund the project. It has the backing of a diverse group of 48 organizations, including paediatric health groups and the industry-funded American Chemistry Council, which announced its support in a letter to the institute on 12 November. "The cost of the study is dwarfed by the cost of treating the diseases and conditions it can be expected to address," the letter states.

The March of Dimes director of public policy and government affairs, Jo Merrill, hopes that such arguments will convince Congress to support the child study, even though spending on domestic programmes has been drastically curtailed because of the US war on terrorism. "We're cautiously optimistic," she says.

\section{Report censures political screening of advisory boards}

Geoff Brumfiel, Washington

Asking scientists questions about their political affiliations before allowing them to serve on government panels is "inappropriate", according to a report from the US National Academies.

The report, issued on 17 November, follows accusations by scientists and watchdog groups earlier this year that the Bush administration had politicized the process of appointing scientific advisory boards. "It is inappropriate to ask [scientists] to provide nonrelevant information, such as voting record, political-party affiliation, or position on particular policies," the report states.

"Cleary this report validates the concern expressed by senior scientists starting last winter about some of these issues," says Alden Meyer, director of strategy and policy at the Union of Concerned Scientists (UCS) in Washington DC. In February, the UCS accused the Bush administration of skewing scientific advice and screening committee members based on political beliefs (see Nature 427, 663; 2004).

Those allegations were viewed by Republicans as a political act, coming as they did in an election year. But Meyer says he believes the new study lends validity to the UCS claims.

"Hopefully, having a committee of this sort come out after the election will carry some weight," he says.

Others are less sanguine about the academies' findings. "I think the report is a little naive," says Vernon Ehlers (Republican, Michigan), a nuclear physicist now serving in the House of Representatives. Ehlers says that although some panels address strictly scientific issues, many scientific advisory groups must wrestle with political issues. In those cases, Ehlers argues, "the president has a right to expect people to be in tune with his policies".

John Marburger, the president's science adviser, agrees that there is "some ambiguity" in the report over how to deal with advisory committees handling highly political topics. But he says the report gives a good overall view of the advisory committee process.

Marburger adds that the use of political questions to screen candidates has been "fairly rare". Still, he says, "if anyone feels they're being asked inappropriate questions in connection with membership on a science advisory committee, I sure would like to know about it". 